\title{
CORRELATION BETWEEN LABORATORY PARAMETERS AND COVID-19 TREATMENT OUTCOME
}

\author{
Ruzica Radojevic-Marjanovic ${ }^{1}$, Valentina Opancina2,3, Kristijan Krstic 3,4, Slobodan Jankovic ${ }^{3,5}$ \\ ${ }^{1}$ University Clinical Centre Kragujevac, Clinic for Infectious and Tropic Diseases, Kragujevac, Serbia \\ ${ }^{2}$ University of Kragujevac, Faculty of Medical Sciences, Department of Radiology, Kragujevac, Serbia \\ ${ }^{3}$ University Clinical Centre Kragujevac, Kragujevac, Serbia
}

${ }^{4}$ University of Kragujevac, Faculty of Medical Sciences, Department of Physical Medicine and Rehabilitation, Kragujevac, Serbia

5 University of Kragujevac, Faculty of Medical Sciences, Department of Pharmacology and Toxicology, Kragujevac, Serbia

\section{POVEZANOST IZMEĐU LABORATORIJSKIH PARAMETARA I ISHODA LEČENJA KOD KOVIDA 19}

\author{
Ružica Radojević-Marjanović1, Valentina Opančina2,3, Kristijan Krstić3,4, Slobodan Janković3,5 \\ ${ }^{1}$ Univerzitetski klinički centar Kragujevac, Klinika za infektivne i tropske bolesti, Kragujevac \\ 2Univerzitet u Kragujevcu, Fakultet medicinskih nauka, Katedra za radiologiju, Kragujevac \\ ${ }^{3}$ Univerzitetski klinički centar Kragujevac, Kragujevac, Srbija \\ ${ }^{4}$ Univerzitet u Kragujevcu, Fakultet medicinskih nauka, Katedra za fizikalnu medicinu i rehabilitaciju, Kragujevac \\ 5 Univerzitet u Kragujevcu, Fakultet medicinskih nauka, Katedra za farmakologiju i toksikologiju, Kragujevac
}

\section{ABSTRACT}

Objective. The aim of this study was to explore the baseline characteristics and correlation of the C-reactive protein, D-dimer, Ferritin and human serum albumins, with the treatment outcome of COVID-19 infection.

Methods. Our study was conducted in the Clinic for infectious diseases at the University Clinical Center Kragujevac during the time frame from November 1 st 2020 to February 1st 2021. It was designed as case series and it included patients of age greater than 18 years and positive Polymerase Chain Reaction test or serological (antigen) test on SARS-COV-2 who were treated at our clinic.

Results. A significant correlation was found between human serum albumins $(\mathrm{g} / \mathrm{L})$ with the outcome variable $p=0.009$, while correlation coefficient was 0.466 . Furthermore, the lower level of albumins was significantly correlated with the intrahospital mortality, with $p=0.007$ and correlation coefficient 0.484 .

Conclusion. Our study results suggest that hypoalbuminemia could be possibly used as a significant prognostic factor for intrahospital mortality in COVID-19 patients.

Key words: COVID-19; laboratories; albumins

\section{INTRODUCTION}

Severe acute respiratory syndrome coronavirus 2 (SARS-CoV-2) causing coronavirus disease 2019 (COVID-19) has rapidly unfolded from an epidemic outbreak in Wuhan, China into a global pandemic of international interest $(1,2)$. The epidemic was declared to be a public health emergency, the highest level of alarm under international law, by the World Health Organization (WHO) on January 30, 2020. Since the start of the pandemic, there has been over 102.1 million reported cases and over 2.2 million deaths globally (3).

\section{SAŽETAK}

Cilj. Cilj ove studije bio je da istraži osnovne karakteristike i korelaciju između C-reaktivnog proteina, $D$ dimera, feritina $i$ albumina sa ishodom lečenja infekcije kovid 19.

Metode. Naše istraživanje je sprovedeno na Klinici za infektivne bolesti Univerzitetskog Kliničkog centra Kragujevac u periodu od 1. novembra 2020. do 1. februara 2021. godine. Dizajnirano je kao serija slučajeva $i$ obuhvatilo je pacijente starije od 18 godina sa pozitivnim rezultatom PCR testa ili serološkog (antigenskog) testa na SARS-COV-2, koji su lečeni na našoj klinici.

Rezultati. Pronađena je značajna korelacija između humanih serumskih albumina $(\mathrm{g} / \mathrm{L})$ sa ishodom lečenja $p=0,009$, dok je koeficijent korelacije bio 0,466. Takođe niži nivo albumina bio je u značajnoj korelaciji sa intrahospitalnim mortalitetom, dok je $p=0,007 i$ koeficijent korelacije bio 0,484.

Zaključak. Rezultati našeg istraživanja sugerišu da bi hipoalbuminemija mogla da se koristi kao značajan prognostički faktor za intrahospitalni mortalitet kod pacijenata sa kovid 19.

Ključne reči: Kovid 19; laboratorije; albumini

It is well known that COVID-19 is primarily manifested as a respiratory tract infection, but due to rapidly changing clinical manifestations, emerging data indicate that it should be regarded as a systemic disease involving multiple systems. The progressive clinical form can lead to multiple organ dysfunction, hypoxia and fatal outcome (1).

There is growing evidence that in critically ill patients, there are tendencies of hyper inflammation, which consist of elevated serum C-reactive protein (CRP) (4,5), D-dimer (6), Ferritin (7), and Human serum albumin (HSA) (8-11). The hyperinflammatory state induces endothelial damage 
Table 1. Characteristics of the study population

\begin{tabular}{|c|c|c|c|c|}
\hline Characteristic & $\begin{array}{c}\text { Total } \\
(\mathrm{n}=30)\end{array}$ & $\begin{array}{c}\text { Died } \\
(\mathrm{n}=11)\end{array}$ & $\begin{array}{c}\text { Survived } \\
(\mathrm{n}=19)\end{array}$ & $\mathrm{P}$ values \\
\hline Age, mean $\pm \mathrm{SD}$ & $63.63 \pm 15.52$ & $67.36 \pm 14.3$ & $61.47 \pm 16.2$ & 0.323 \\
\hline Male gender, $\mathrm{n}(\%)$ & $20(66.7)$ & $6(20)$ & $14(46.7)$ & 0.284 \\
\hline $\mathrm{HSA}$, mean $\pm \mathrm{SD}$ & $34.13 \pm 4.5$ & $31.54 \pm 3.9$ & $35.63 \pm 4.2$ & 0.932 \\
\hline Low HSA, n (\%) & $15(50)$ & $9(30)$ & $6(20)$ & 0.008 \\
\hline $\mathrm{CRP}$, mean $\pm \mathrm{SD}$ & $126.48 \pm 154.23$ & $146.97 \pm 105.3$ & $114.62 \pm 178.2$ & 0.717 \\
\hline High CRP, n (\%) & $29(96.7)$ & $11(36.7)$ & $18(60)$ & 0.439 \\
\hline Ferritin, mean $\pm \mathrm{SD}$ & $742.07 \pm 767.86$ & $918.20 \pm 1159.5$ & $638.47 \pm 413.5$ & 0.200 \\
\hline High ferritin, n (\%) & $22(81.5)$ & $9(33.3)$ & $13(48.1)$ & 0.382 \\
\hline D-dimer, mean $\pm \mathrm{SD}$ & $2.86 \pm 5.55$ & $2.21 \pm 1.9$ & $3.2 \pm 6.7$ & 0.335 \\
\hline High D-dimer, n (\%) & $26(89.7)$ & $9(31)$ & $17(58.6)$ & 0.965 \\
\hline
\end{tabular}

* SD-standard deviation, HSA-human serum albumin, CRP- C reactive protein

after a great production of cytokines, which in large number of cases leads to acute respiratory syndrome (11). These markers are standard laboratory markers done in patients infected with SARS-COV-2. Furthermore, there is a wide array of laboratory testing that is done in COVID-19 patients. Given that, there are certain cardiac markers such as Myo-proBNP and NT-proBNP which have been shown to be strongly correlated with intrahospital mortality in noncardiac patients (12). Also, there are studies which suggest that age, CRP and Interleukin- 6 are independent predictor of intrahospital mortality, while the decline in D-dimer and CRP level were associated with the good prognosis of treatment outcome (13). Besides, new biomarkers for COVID-19 are constantly arising. One of them is neopterin which is produced by monocytes and macrophages after the activation which is initiated by interferon-gamma (14). Recent studies suggest that this marker could be a useful tool for prediction of the bad outcome and severity of the disease in COVID-19 patients (14).

The aim of this study was to explore the baseline characteristics and correlation of the CRP, D-dimer, Ferritin and HSA, with the treatment outcome of COVID-19 infection.

\section{PATIENTS AND METHODS}

Our study was conducted in the Clinic for Infectious Diseases at the University Clinical Center Kragujevac during the time frame from November 1st 2020 to February 1st 2021. The study was approved from the Institutional Ethical Committee and it was in compliance with Helsinki Declaration.

The study was designed as case series and it included patients of age greater than 18 years and positive Polymerase Chain Reaction (PCR) test or serological (antigen) test on SARS-COV-2 who were treated at the Clinic for Infectious Diseases. Study data was collected from the patients' clinical histories.

The following variables were examined: age, gender, level of HSA on admission, level of CRP on admission, ferritin level on admission and D-dimer level on admission. The dependent variable was outcome of the hospitalization. Furthermore, all the patients were divided in two groups depending on the treatment outcome. The first group included patients who died during the hospitalization and the second group included patients who were successfully treated and who recovered.

Laboratory values were obtained on the admission, from the blood sample, by standard laboratory tests. Hypoalbuminemia was determined as a serum albumin concentration which was less than $35 \mathrm{~g} / \mathrm{L}$, normal serum ferritin level was 20-300 $\mathrm{ng} / \mathrm{mL}$, normal serum CRP concentration was $\leq 5 \mathrm{mg} / \mathrm{L}$, whereas higher values indicated microinflammation. Also, normal D-dimer values were less than $0.5 \mathrm{mg} / \mathrm{L}$.

The software used for the analyses was the SPSS version 23 (SPSS Inc, Chicago, IL). The study data were tested by descriptive statistics. The continuous variables were presented by mean \pm standard deviation. Also, categorical variables were depicted with rates and percentages. The continuous variables were compared using Wilcoxon's rank sum or Kruskal Wallis test, while $\chi^{2}$ test was used for the categorical variables. $P$ value was significant if less than 0.05 . Non-parametric analysis of the correlation between HAS, CRP, D-dimer, ferritin and outcome of the hospitalization was determined by point biserial correlation. Point biserial correlation test was also used to compare data between levels of serum albumin concentration and disease outcome. Pearson correlation was .445 which means that lower levels of serum albumin concentration are associated with more frequent death outcomes.

\section{RESULTS}

Our study included 30 COVID-19 positive patients. Out of them $66.7 \%$ were men and $33.3 \%$ were women, while mean age \pm standard deviation was $63.63 \pm 15.52$. The characteristics of the study participants are presented in Table 1. 


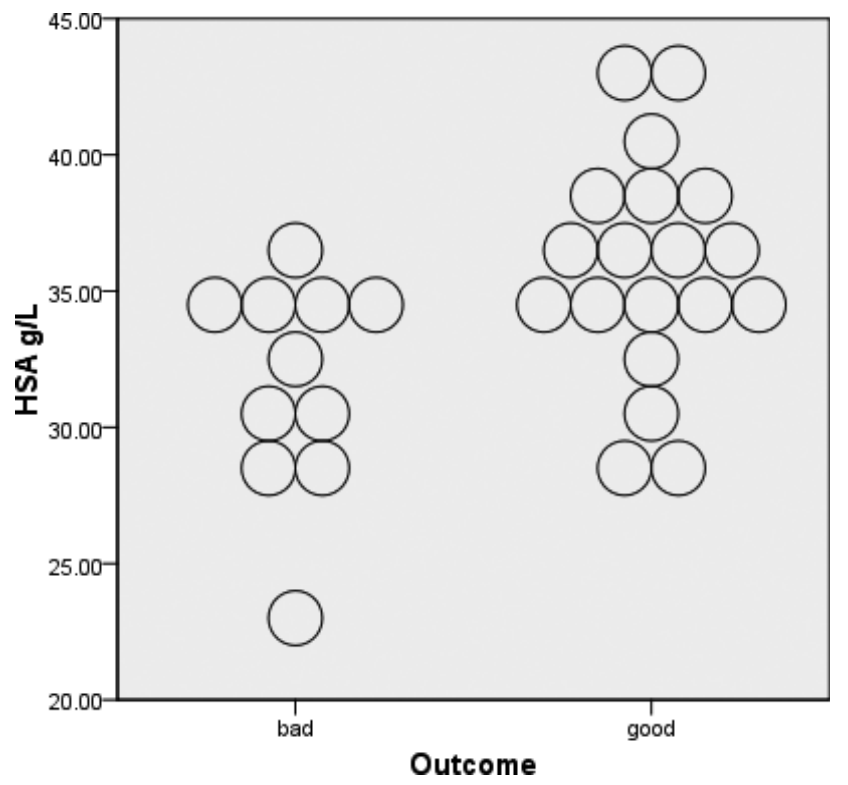

Figure 1. Correlation between hypoalbuminemia and intrahospital mortality

A significant correlation was found between HSA (g/L) with the outcome variable $\mathrm{p}=0.009$, while correlation coefficient was 0.466 . This correlation is presented in dot plot in Figure 1. Also, a lower level of HSA was significantly correlated with the intrahospital mortality, with $\mathrm{p}=0.007$ and correlation coefficient 0.484 . None of the other examined variables showed significant correlation with the outcome. When correlating biomarkers between themselves, we noticed negative correlation coefficients between: HSA and CRP (-0.259), HSA and Ferritin (-0.261), HSA and D-dimer (-0.340).

\section{DISCUSSION}

Our study results showed a significant correlation between hypoalbuminemia and intrahospital mortality in COVID-19 patients. The other inspected laboratory markers: C-reactive protein, ferritin, D-dimer didn't show a significant correlation with the outcome.

There is a small number of recently published studies that suggest that lower levels of HSA are strong predictors for patients' mortality during hospital treatment $(11,14)$. One of the meta-analysis presented that hypoalbuminemia is significantly contributing to the adverse outcomes and severity of the disease in patients infected with SARSCoV-2 (14). The same study suggested that CRP $(\mathrm{p}=0.019)$, age and white blood cell count, play a significant role in the between-study variance (14). Also, other researchers suggested that HSA could be used as a prognostic factor for a higher risk of mortality in COVID19 patients (hazard ratio: $0.38,95 \%$ confidence interval CI: $0.23-0.63, \mathrm{p}<0.001$ (15).

Still, there is no definite pathological mechanism which was described for the role of low HSA in prediction of COVID-19 mortality (11). Human serum albumin is a reactant with antioxidant properties. Under conditions of oxidative stress, HSA may sustain irreversible oxidation, which impairs antioxidant property and eventually causes tissue damage. Serum albumin levels $<30 \mathrm{~g} / \mathrm{L}$ were found in $105 / 207(50.7 \%)$ patients at hospital admission. Overall, the median albumin value was $29.5 \mathrm{~g} / \mathrm{L}$ (IQR 2532.8). A negative association was found between albumin levels and severity of COVID-19 $(\mathrm{P}<.0001)$ and death $(\mathrm{P}=.003)$. An inverse correlation was observed between albumin and both $\mathrm{C}$-reactive protein and D-dimer at hospital admission $(\mathrm{r}=-.487$ and $\mathrm{r}=-.479$, respectively; $\mathrm{P}<.0001)(11)$.

Also, our study showed negative correlation coefficient between examined laboratory markers, which was the same case as in the previously published study which showed inverse correlation between HSA and both CRP and D-dimer values: $-0.487,-0.479$ (11). Our study had smaller sample of investigated patients, but showed similar results as well as inverse correlation between HSA and both CRP and D-dimer values: $-0.259,-0.340$

Our study was conducted in a single center and it included a small number of patients. The strong connection we found between hypoalbuminemia and intrahospital mortality was found only by univariant analyses. This should be proven by multivariate logistic regression, which should also include a greater number of other variables. Given that, we encourage more studies on this topic.

In conclusion, there is a rapid change of clinical manifestations of COVID-19 as well as prognostic factors for the severity of the disease and the potential death outcome. Our results suggest that hypoalbuminemia could possibly be used as a significant prognostic factor for intrahospital mortality in these patients. However, this is only one correlation, and we should not rapidly conclude based on this.

\section{REFERENCES}

1. Huang C, Wang Y, Li X, et al. Clinical features of patients infected with 2019 novel coronavirus in Wuhan, China. Lancet 2020; 395: 497-506.

2. Wang $\mathrm{D}, \mathrm{Hu} \mathrm{B}, \mathrm{Hu} \mathrm{C}$, et al. Clinical characteristics of 138 hospitalized patients with 2019 novel coronavirusinfected pneumonia in Wuhan, China. JAMA 2020; 323: 1061-9.

3. World Health Organization. World Health Organization. Coronavirus disease 2019 (COVID-19) Situation Report - 106. Geneva: World Health Organization, 2020. (https://www.who.int/emergencies/diseases/ novel-coronavirus-2019/ situation-reports). 
4. Warusevitane A, Karunatilake D, Sim J, Smith C, Roffe C. Early diag-nosis of pneumonia in severe stroke: clinical features and thediagnostic role of Creactive protein. PloS One 2016; 11: e0150269.

5. Matsumoto H, Kasai T, Sato A, et al. Association between C-reactive protein levels at hospital admission and long-term mortality in patients with acute decompensated heart failure. Heart Vessels 2019; 34: 1961-8.

6. Luo WR, Yu H, Gou JZ, et al. Histopathologic findings in the explant lungs of a patient with COVID-19 treated with bilateral orthotopic lung transplant. Transplantation 2020; 104: e329-e331.

7. Momeni A, Behradmanesh MS, Kheiri S, Abasi F. Serum ferritin has correlation with $\mathrm{HbA1c}$ in type 2 diabetic patients. Adv Biomed Res 2015; 4: 74.

8. Chen $\mathrm{G}$, Wu D, Guo W, et al. Clinical and immunological features of severe and moderate coronavirus disease 2019. J Clin Invest 2020; 130: 2620-9.

9. Chen N, Zhou M, Dong X, et al. Epidemiological and clinical characteristics of 99 cases of 2019 novel coronavirus pneumonia in Wuhan, China: a descriptive study. Lancet 2020; 395: 507-3.

10. Henry BM, de Oliveira MHS, Benoit S, Plebani M, Lippi G. Hematologic, biochemical and immune biomarker abnormalities associated with severe illness and mortality in coronavirus disease 2019 (COVID19): a meta-analysis. Clin Chem Lab Med 2020; 58: 1021-8.
11. Bassoli C, Oreni L, Ballone E, et al. Role of serum albumin and proteinuria in patients with SARS-CoV-2 pneumonia. Int J Clin Pract 2020: e13946.

12. Yu JS, Pan NN, Chen RD, Zeng LC, Yang HK, Li H. Cardiac Biomarker Levels and Their Prognostic Values in COVID-19 Patients With or Without Concomitant Cardiac Disease. Front Cardiovasc Med 2021; 7: 599096.

13. Li T, Wang X, Zhuang X, et al. Baseline characteristics and changes of biomarkers in disease course predict prognosis of patients with COVID-19. Intern Emerg Med 2021; 10: 1-8.

14. Paliogiannis P, Mangoni AA, Cangemi M, Fois AG, Carru C, Zinellu A. Serum albumin concentrations are associated with disease severity and outcomes in coronavirus 19 disease (COVID-19): a systematic review and meta-analysis. Clin Exp Med 2021; 28: $1-12$.

15. Violi F, Cangemi R, Romiti GF, et al. Is Albumin Predictor of Mortality in COVID-19? Antioxid Redox Signal 2020. (doi: 10.1089/ars.2020.8142). 